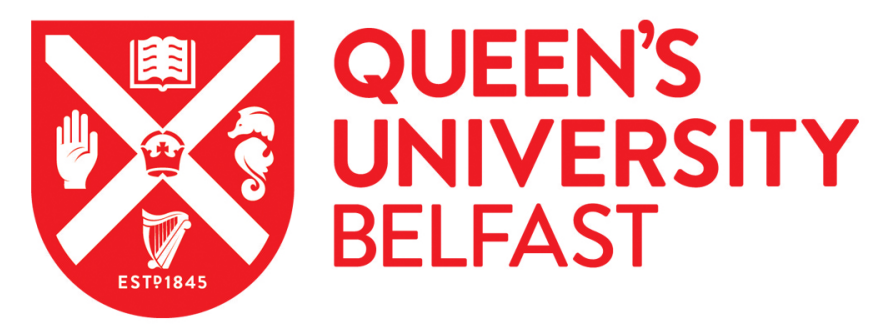

\title{
The democratic legitimacy of orchestration: the UNFCCC, non-state actors, and transnational climate governance
}

Bäckstrand, K., \& Kuyper, J. W. (2017). The democratic legitimacy of orchestration: the UNFCCC, non-state actors, and transnational climate governance. Environmental Politics, 26(4), 764-788.

https://doi.org/10.1080/09644016.2017.1323579

Published in:

Environmental Politics

Document Version:

Peer reviewed version

Queen's University Belfast - Research Portal:

Link to publication record in Queen's University Belfast Research Portal

Publisher rights

Copyright 2017 Taylor and Francis. This work is made available online in accordance with the publisher's policies. Please refer to any applicable terms of use of the publisher.

\section{General rights}

Copyright for the publications made accessible via the Queen's University Belfast Research Portal is retained by the author(s) and / or other copyright owners and it is a condition of accessing these publications that users recognise and abide by the legal requirements associated with these rights.

Take down policy

The Research Portal is Queen's institutional repository that provides access to Queen's research output. Every effort has been made to ensure that content in the Research Portal does not infringe any person's rights, or applicable UK laws. If you discover content in the Research Portal that you believe breaches copyright or violates any law, please contact openaccess@qub.ac.uk. 


\title{
Title Page
}

The democratic legitimacy of orchestration:

\section{The UNFCCC, non-state actors, and transnational climate governance}

Karin Bäckstrand (corresponding author)

Department of Political Science, Stockholm University, Stockholm, Sweden. karin.backstrand@statsvet.su.se

and

Jonathan W. Kuyper, Department of Political Science, University of Oslo, Oslo, Norway and Research Fellow, Department of Political Science, Stockholm University, Stockholm, Sweden.

jonathan.kuyper1@gmail.com

\begin{abstract}
Is orchestration democratically legitimate? The importance of this question is signaled by recent theoretical and empirical developments of international organizations. On one hand, debates concerning the legitimacy and democratic deficits of international politics continue unabated. On the other, the Secretariat of the United Nations Framework Convention on Climate Change (UNFCCC) has progressively engaged in processes of orchestration culminating in the 2015 Paris Agreement. Scholarship on orchestration has almost exclusively focused on how to ensure effectiveness while excluding normative questions. This lacuna is addressed by arguing that orchestration should be assessed according to its democratic credentials. The promises and pitfalls of orchestration can be usefully analyzed by applying a set of democratic values: participation, deliberation, accountability, and transparency. Two major orchestration efforts by the UNFCCC both pre- and post-Paris are shown to have substantive democratic shortfalls, not least with regard to participation and accountability. Ways of strengthening the democratic legitimacy of orchestration are identified.
\end{abstract}

\section{Keywords (3-5):}

Democratic legitimacy; UNFCCC; orchestration; non-state actors 


\section{The democratic legitimacy of orchestration:}

\section{The UNFCCC, non-state actors, and transnational climate governance}

\section{Introduction}

For almost a decade, states have struggled to craft a successor agreement to the Kyoto Protocol within the confines of the United Nations Framework Convention on Climate Change (UNFCCC). Following the adoption of the 2009 Copenhagen Accord at the $15^{\text {th }}$ Conference of the Parties (COP), the multilateral climate regime was labeled as gridlocked: unable to produce a legally binding agreement with quantitative emission reduction targets for greenhouse gas emissions, states turned toward a weak set of voluntary pledges instead. Stalemate at Copenhagen meant attention shifted away from the inter-state bargaining process toward the wider climate landscape of initiatives by states, sub-state actors, and civil society (Hoffmann 2011).

In December of 2015, however, gridlock was overcome with the adoption of the widely heralded Paris Agreement that entered in to force on November $4^{\text {th }} 2016$ (UNFCCC 2015b). Building on the Copenhagen Accord, the bedrock of the Paris Agreement is the voluntary 'nationally determined contributions' (NDCs) that rely upon states making commitments to reduce emissions, adapt to climate change, and provide finance. There are no legally binding targets for countries but rather a binding process for transparent review designed to make states ratchet up these commitments over time (Clemenson 2016, p. 7).

Along with these NDCs, a crucial outcome of the Paris Agreement is that the UNFCCC has been consolidated as the central orchestrator of non-state actors and transnational initiatives in global climate governance. Orchestration is a strategy in which international organizations (IOs) and states mobilize intermediaries - private actors, civil society, transnational networks, and sub-state actors - to direct targets in the pursuit of key collective goals (Abbott et al. 2015a, Hale and Roger 2014). The solidification of the UNFCCC as orchestrator builds upon several years of activity by the Secretariat and state governments to coordinate, harness, and mobilize non-state actors (or, in the nomenclature of the Paris Agreement, non-party stakeholders).

In particular, the Paris Agreement reflects a process whereby the UNFCCC Secretariat, by itself or jointly with states and other IOs, orchestrates various platforms of non-state climate commitments (Hale 2016). Likewise, the COP decision 
annexed to the Paris Agreement authorized the appointment of two High-Level Champions with a full-time job to mobilize non-state climate action, and engage nonstate actors for the pre-2020 period (UNFCCC 2015c). ${ }^{1}$ To this end, the French Presidency of COP21 and the Moroccan Presidency of COP22 nominated each a senior diplomat for 2016-2018 culminating in the adoption of the Marrakech Partnership for Global Climate Action (GCA) (UNFCCC 2016a).

Tracking these empirical developments, a vibrant literature has emerged focusing on how and why IOs engage orchestration as a mode of governance. Applied to climate governance, this work has looked at the mechanisms through which the UNFCCC Secretariat seeks to catalyze non-state action to put the world on track to limit global warming to well below 2 degrees, promote climate resilience, and push for de-carbonization (Chan et al. 2016; Chan et al. 2015, Hsu et al. 2015). The core question guiding this research is how to align non-state and intergovernmental action to achieve a low carbon future, focusing primarily on the effectiveness of orchestration to enlist intermediaries such as business, public-private partnerships, and cities to reach governance goals.

Here, we focus on a different question: is orchestration democratically legitimate? In answering this question, we develop a framework anchored in 'democratic values' - equal participation, deliberation, accountability, and transparency - for analyzing the legitimacy of orchestration. We engage in novel empirical analysis of two orchestration efforts undertaken by the UNFCCC Secretariat jointly with COP presidencies and the United Nation Secretary-General, namely the Lima-Paris Action Agenda (LPAA) and the Non-state Actor Zone for Climate Action (NAZCA), which were further consolidated in GCA. We analyze these two orchestration mechanisms by applying the democratic values framework and find substantial shortcomings in participation, transparency, and accountability. We also find positive examples, though, which provide ways to make orchestration more democratically legitimate.

Methodologically, this analysis amounts to an illustrative case-study that identifies, maps, and evaluates the democratic legitimacy of two orchestration efforts. The empirical material for this paper is based primarily on qualitative data, such as

\footnotetext{
${ }^{1}$ Respectively, the High-Level Champion assigned by the French Presidency and the Moroccan Presidency are Laurence Tubiana and Hakima El Hatté. See http://www.cop22.ma/en/node/842 (accessed 20 April 2017).
} 
UNFCCC documents and official treaty texts, platforms of voluntary climate commitments, position papers, websites of different non-state actors, and summaries of sessions by the Earth Negotiation Bulletin. Moreover, a background for this paper is participatory observation and 50 semi-structured interviews with state and non-state actors at COP 19-21 and Bonn Intersessionals from the same time period. ${ }^{2}$

The discussion moves forward in five stages. First, we define orchestration, expound previous research on the topic, and highlight the normative importance of linking orchestration with democratic legitimacy. Second, we detail our argument for attaining democratic legitimacy in orchestration through a focus on democratic values. Third, we conceptualize how the orchestrator-intermediaries-target relationship operates in the UNFCCC through "meta-intermediaries" of LPAA and NAZCA. Fourth, we assess to what extent these orchestration strategies by the UNFCCC live up to these democratic values. The conclusion discusses how state and non-state actors interact in climate governance and emphasizes the importance of building democratic legitimacy in the post-Paris regime.

\section{Orchestration and the Democratic Deficit}

\section{Orchestration and Global Governance}

Global governance - the collection of formal and informal institutions that create, alter, and propagate the rules and norms dictating state and non-state interactions in world politics - is increasingly dense and complex. As a result of this complexity, states and IOs are steadily employing orchestration to solve collective action problems and manage global governance (Abbott et al. 2015a). Orchestration, as illustrated in Figure 1, can be conceptualized in terms of an OrchestratorIntermediary-Target (O-I-T) relationship. Here, orchestrators - such as IOs and states - seek to mobilize intermediaries - non-state actors, IGOs, transgovernmental networks, etc. - on a voluntary basis to impact targets in pursuit of a governance goal. Orchestration is indirect and soft as the IO addresses the ultimate targets - such as consumers, states, or firms - via intermediaries and because the orchestrator lacks hard control over this chain. Through this mode of governance, the orchestrator grants

\footnotetext{
${ }^{2}$ Details on file with authors.
} 
material and ideational resources to the intermediary party who can attempt to pursue their goals without binding restrictions from the orchestrator. Orchestrators often employ 'meta-intermediaries' - institutional mechanisms - that organize intermediaries.

It is now widely recognized that orchestration is a key mode of global governance. Under what conditions is orchestration likely to emerge as a dominant strategy? Abbott et al. (2015a, p. 20ff) explicate a number of general and specific hypotheses to explain why an IO chooses orchestration instead of delegation. Factors such as limited orchestrator capability (the IO has low governance capacity but there is availability of multiple intermediaries) and strong orchestrator focality (the IOs is the uncontested and most legitimate actor in the field) explain the choice to engage orchestration. Moreover, orchestration is likely to emerge when there is goal divergence among member states (or between member states and IOs) and if member states have weak institutional control mechanisms.

Given above explanations for the emergence of orchestration we argue that UNFCCC fits well with the orchestration theory. First, the UNFCCC has relative limited governance capacity in terms of staff and budget compared to other IOs. Second, there is a large availability of intermediaries in climate governance: transgovernmental networks, civil society, scientific and investors. Third, there is strong focality as UNFCCC remains the leading IO in global climate governance not least after the Paris Agreement. Fourth, there is a goal divergence among the Parties due the problem structure of climate change as a wicked problem with asymmetrical distribution of negative impacts of climate change and varying vulnerability to climate change.

[Insert Figure: "Orchestration" about here]

\section{Global Governance and Democratic Legitimacy}

The growth of activity beyond the state has given risen to discussions over the democratic deficit of global (climate) governance. This work predominantly recognizes that the authority once confined within national borders increasingly escapes these traditional demarcations (Stevenson and Dryzek 2014, p. 6). The democratic deficit arises because, while democratic institutions remain tied to nation- 
state boundaries, authority does not. Individuals are therefore affected by decisions that they have not had equal say in formulating. This directly undercuts the intrinsic value of democracy in which the people govern themselves.

While much ink has been spilled describing the democratic deficit in global governance, recent scholarship has honed in on instrumental reasons why it should be mitigated. Not only is democracy an important source of legitimacy for modern governance, empirical work continues to show that democratic procedures promote better (epistemic) decision-making and generate greater compliance compared to other modes of governance (Kuyper 2015). A key finding from scholars of global governance is that democratic legitimacy matters for the performance of global governance institutions (Dingwerth 2007). Therefore the effectiveness of orchestration may relate systematically to the legitimacy of that governance arrangement in ways that require unpacking. Based on both intrinsic and instrumental reasons, we think there are good reasons to continue probing the democratic legitimacy of global governance.

\section{Orchestration and Democratic Legitimacy}

Although work on orchestration has focused myopically on effectiveness, the persistence and proliferation of this practice also raises normative questions such as those surrounding democratic legitimacy. At its core, democratic legitimacy is required so that individuals significantly affected by the use of authority have equal say in how that authority is used. Because the usage of orchestration by bodies such as the UNFCCC involves the exercise of public authority to achieve policy goals in ways that directly affect individuals, we argue that the decision to engage in orchestration by IOs and states, as well as the ongoing relationship between orchestrator-intermediary-target, should be democratically legitimated. The burden for ensuring the standards of democratic are maintained falls predominantly on the orchestrator. We discuss three specific reasons showing how orchestration generates demands of democratic legitimacy.

First, the decision by IOs to engage in orchestration entails an act of public authority. The cornerstone of democratic legitimacy is that justifications for authority should be offered to those affected by that rule-making. Orchestration by the UNFCCC Secretariat necessitates the creation of policies and rules surrounding how 
orchestration efforts should be created, managed, and assessed. The Secretariat therefore uses its authority to forge rules, expend resources, and shape the practices of intermediaries and, by extension, the effects on targets. Given that the Secretariat uses its authority to take these steps, the decision to engage in orchestration requires legitimation.

Second, it might be argued that orchestration does not trigger a demand for democratic legitimacy because the authority of the UNFCCC Secretariat is delegated from states which are, in turn, democratically legitimated at the national level. There are, however, several problems with this claim (for a similar argument, see Moravcsik 2004). Although the UNFCCC has 197 member states, many of them do not qualify as democratic, therefore removing their citizens from the chain of delegation. Relatedly, the authority exercised by international bureaucracies is increasingly removed from delegation chains through processes of agency slack in which agents carve out space to exercise authority beyond that which was delegated to them (Johnson 2013). This also severs individuals from the exercise of authority.

Perhaps more directly, though, the practice of orchestration breaks chains of delegation between citizens who empower states and IOs with the activities of intermediaries that are recognized, mobilized, and even sanctioned by the orchestrator. Orchestrated governance is soft and the orchestrator does not have final say over intermediaries and their activities. Resultantly, there is no delegated authority that can be taken back by the IO or state governments. This lack of delegation places the democratic legitimacy of orchestration at the fore. This is a point recognized in a recent article by Kenneth Abbott and his co-authors (2015b) as they highlight the legitimacy complications engendered by orchestration. Abbott et al. (2015b, p. 9) claim that orchestration, in contrast to delegation, 'cuts the chain of electoral accountability because the orchestrator lacks hard control over intermediaries. Ultimately, intermediaries exercise their authority in an (externally) uncontrolled and unaccountable way.' As a result, they contend that this form of governance 'cannot simply be subsumed under delegation, but demands its own form of analysis.' We agree with this point and suggest that because orchestration cuts the ties between national constituents on one hand and intermediaries and targets on the other, the decision to engage in orchestration requires democratic legitimation.

Finally, some instances of orchestration entail activities by intermediaries which impact significantly upon targets. While not all orchestration efforts will reach 
this bar, those by the UNFCCC discussed in this article do. Both LPAA and NAZCA, which provide organizing platforms for intermediaries, are endorsed in the COP decision to the Paris Agreement (UNFCCC 2015c). Moreover, the UNFCCC, through the two High Level Champions, maintains that the activities of intermediaries will be essential to close the 14-17 gigaton emission gap as states strive toward a less than 2degree pathway. ${ }^{3}$ The decision to undertake orchestration by the UNFCCC provides resources and recognition to intermediaries as well as legitimates their activities. Given that the Secretariat employs public authority to maintain orchestration platforms, as well as highlights the importance of these efforts in supporting NDCs (UNFCCC 2016a), it is essential that the intermediary activities contribute clearly to the core goal of the UNFCCC and the Paris Agreement.

Taken together, these points highlight why the democratic credentials of orchestration should be taken seriously. The use of authority by the orchestrator, as well as potential impacts of intermediaries, places a burden on the orchestrator to ensure that the decision to use authority to engage in orchestration, as well as ongoing intermediary efforts, live up to democratic standards.

\section{Towards Democratic Legitimacy Beyond the State: A Democratic Values}

\section{Approach}

How should we assess democratic legitimacy beyond the state, especially in the context of orchestration? We suggest that adopting a 'democratic values' approach is fruitful. Building on work such as Dingwerth (2007), this approach seeks to remedy the global democratic deficit by enhancing and deepening a set of democratic values in formal and informal institutions. In this way the democratization of climate governance can be seen as a set of values that that are more or less met. We can evaluate how orchestration fares in terms of each value and then prescribe ways to enhance these values.

We recognize there are other ways to think about the democratization of climate governance. For instance, different scholars have focused on an intergovernmental approach (Keohane et al. 2009), a stakeholder model (Macdonald

\footnotetext{
${ }^{3}$ See: http://unfccc.int/files/paris_agreement/application/pdf/marrakech_partnership_for_global_climate_acti on.pdf (accessed 20 April 2017).
} 
2008), or deliberative democratization (Stevenson and Dryzek 2014). While these models all have their relative merits, we choose to adopt the 'democratic values approach' for two key reasons. First, given orchestration is a relatively new phenomenon, it is important to have an open conceptualization about how democracy might be pursued under these conditions. Second, recent literature has stressed that thinking about democratization in terms of a set of values helps make clear that potential trade-offs and symbiosis between those values (Dingwerth 2014).

The key question is then which democratic values should different actors pursue and promote? In assessing the democratic legitimacy of orchestration strategies we focus on participation, deliberation, accountability, and transparency. We focus on these values because have they reflect several prominent traditions in democratic thinking, such participatory, deliberative, and liberal models. Moreover taken together these values uphold the core of democracy by providing individuals control over authority which significantly affects their life by participating in how that authority is used, demanding justifications, and holding power-wielders accountable in light of transparent information. We measure how well each value is instantiated on a four-fold range: 'significant' presence, 'limited' presence, 'nascent' presence, and 'absent' (see Table 3). The empirical case is then judged against these idealized democratic values.

Participation means that citizens affected by the exercise of authority should have the opportunity and ability to be involved in how that authority is wielded. This entails equal capacity to set the agenda as well as shape the rules, laws, and regulations that will affect their lives. We recognize that equality of participation may often rest upon forms of representation as individuals cannot always be directly involved in all decision-making processes. National representatives or self-appointed representatives (interest groups, non-governmental organizations (NGOs), etc.) can all help connect individuals with sites of authority (Macdonald 2008). Precisely how equal participation is secured will and should vary depending upon the institutional scheme in need of democratic regulation, in this case orchestration.

Deliberation provides those affected by decisions with a rationale for how rules are being formulated and applied in various contexts (Habermas 1996). This value derives largely from work in the field of deliberative democracy that stresses the importance of providing reciprocal and generalizable arguments for how authority is exercised and how it is connected to the public use of reasoning. Reciprocity means 
that justification is mutually acceptable to parties in a deliberation, whereas generalizability connotes a set of reasons that could be shared by affected parties due to shared institutional or moral structures. Deliberation also means that representatives of those affected have an opportunity to put their reasons forward and have a response.

Accountability, in a democratic sense, means that those affected by decisionmaking should have the right to hold power wielders 'to a set of standards, to judge whether they have fulfilled their responsibilities in light of these standards, and to impose sanctions if they determine that these responsibilities have not been met' (Grant and Keohane 2005). This criterion, following liberal conceptions of democracy, gives affected individuals the opportunity to hold decision-makers at different levels of governance accountable for their actions and stop the arbitrary exercise of authority that can undercut individual autonomy. Operative accountability mechanisms provide an ex ante incentive for decision-makers to take consideration of how affected parties will react to decisions being made in their name.

Finally, in order for accountability to be meaningfully enacted, transparency is required. We conceptualize transparency as the means of disclosure of actions taken by public actors and institutions. Transparency should be offered to those affected by decisions. Although it does not require third party monitoring, transparency is often promoted and enhanced by demands for information. Several scholars have claimed that accountability can only be democratically useful if transparent information is available (Peixoto 2013). Due to the close connections between accountability and transparency, we analyze these values together.

[Insert "Table 1: Standards for Assessing Democratic Legitimacy" about here]

\section{UNFCCC and Non-State Actors in Climate Governance: From Regulation to}

\section{Orchestration}

The regime complex of climate governance comprises state governments, the UNFCCC, other IOs (such as the HLPF on sustainable development), NGOs, PPPs, transgovernmental networks, and much more. Within this complex, the UNFCCC has stood at the center of efforts to mitigate greenhouse gas emissions and other anthropogenic interferences with the global climate system for more than 20 years. 
Up until Copenhagen, the strategy for addressing climate change was a top-down 'targets and timetable' approach administered through the Kyoto Protocol. Gridlock at COP15 resulted in the Copenhagen Accord which paved the way for a bottom-up 'pledge-and-review' process whereby industrialized states submitted their voluntary pledges for climate mitigation through Nationally Appropriate Mitigation Actions. COP15 thus fundamentally changed climate diplomacy by shifting from centralized bargaining to national plans aligned with the varying state interests (Falkner 2016).

This bottom-up logic was reinforced at subsequent UN climate summits in Cancun, Durban, and Warsaw. In the wake of the 2014 Lima COP, all states were asked to begin submitting intended NDCs. The Paris Agreement formalized this pledge-and-review system of voluntary commitments by establishing five-year 'global stocktakes' of NDCs coupled with a transparency framework - which engages non-state actors - for assessing the comparability of these pledges in an effort to ratchet up ambitions (UNFCCC 2015b). Along with these changes, the UNFCCC has constructed meta-intermediaries in an effort to move from regulation to orchestration (Abbott and Bernstein 2015). In this article, we focus on two of these efforts: NAZCA and LPAA. In doing so, we exclude databases, registries and platforms of initiatives that are not orchestrated by the UN (Bulkeley et al. 2014). ${ }^{4}$ We also limit ourselves to climate commitments, noting however that they overlap with numerous orchestrating attempts such UN voluntary commitments for sustainable development. ${ }^{5}$

At COP20 in Lima, the COP Presidencies of Peru and France, in tandem with the Executive Office of the United Nation Secretary-General and the UNFCCC Secretariat, launched the LPAA intended to scale-up and showcase non-state climate action. The LPAA - which was framed as the 'fourth pillar' of COP21 alongside mitigation, adaptation and finance - fulfills the function of showcasing initiatives, enhancing ambition, and tracking and reporting of non-state actions. At COP21 in Paris 75 LPAA initiatives were highlighted through a series of high-level thematic events or 7 'Action days'. In order to be showcased under the LPAA banner certain criteria has to be fulfilled for initiatives such as short-term operational goals, implementation capacity, and science based targets. COP21 formally recognized the results of LPAA and decided that a high-level event dedicated for non-state action

\footnotetext{
${ }^{4}$ http://climateinitiativesplatform.org/index.php/Welcome (accessed 15 February 2016).

5 https://sustainabledevelopment.un.org/partnerships (accessed 15 February 2016).
} 
should be convened at each COP until 2020. The GCA adopted in Marrakech represents a continuity of LPAA(UNFCCC 2016b).

Alongside LPAA, the NAZCA platform was launched at the COP20. It is an online portal and aggregator of climate actions from sub-state and non-state actors. Operated by the UNFCCC Secretariat it contains more than 12000 individual and cooperative initiatives. Commitments are supposed to have relevance, scale, specificity in terms of quantifiable outcomes, transparency in tracking progress, and ownership to qualify for NAZCA (UNFCCC 2016a). Amongst others, UNEP, the CDP, the UN Global Compact and Carbon $n$ are supposed to monitor contributions NAZCA by tracking and assessing data. The NAZCA website was refurbished at COP22 in Marrakech and a 'Yearbook of climate action' as reporting mechanism was proposed. Under the GCA, there is an ongoing debate whether NAZCA should remain a permanent platform for compiling, registering, and tracking non-state action according to fulfillment of specific criteria with a more rigorous reporting, monitoring and verification (UNFCCC 2016a)

We argue that NAZCA and LPAA can be conceived as instruments orchestrated by multilateral institutions to catalyze new non-state and sub-state initiatives where needed, support weak organizations and vulnerable regions, strengthen ambition and scale-up climate action to ensure that the mitigation gap is closed. These are steps towards stronger linkages between multilateral negotiations and the sphere of transnational action (Chan et al. 2016, Hale 2016).

\section{Orchestrator-Intermediary-Target and the UNFCCC}

As previously discussed, orchestration can be systematically described in terms of the O-I-T relationship. How does the O-I-T relationship operate in the LPAA and NAZCA, and what are tools of orchestration employed by UNFCCC?

Orchestrator: As detailed in Table 2, the orchestrator for LPAA was a 'quartet' of the Peruvian and French COP Presidencies, the UNFCCC and the United Nation Secretary-General. NAZCA, in a slightly different vein, is hosted by the UNFCCC Secretariat and is designed to improve the visibility of initiatives for mitigating carbon emissions. In both instances, the High-Level Champions are important tools for orchestration intend to scale-up, showcase, and assess non-state initiatives through a roadmap for global climate action (UNFCCC 2016b). We 
differentiate between 'high-level' or summitry orchestration from other orchestration mechanisms that rely on a 'bottom-up' pledging and self-reporting by non-state actors in the form of registries or platforms: The LPAA constitutes an instance of high-level orchestration while the NAZCA platform relies on voluntary bottom-up reporting of actions, commitments, and pledges by actors.

Intermediaries: Orchestration aims to identify, enlist, support, or even create intermediaries that have goals aligned with orchestrator as well as capabilities to address targets, such as states and private entities. Compared to many other policy fields, climate governance has a large availability of intermediaries such as businesses, cities, transgovernmental networks, and scientists. The lead up to the Paris Agreement meant the creation of new intermediaries by orchestrators, or rather what Abbott and Bernstein (2015, p. 229) coin meta-intermediaries, i.e. transnational actors that act as standard-setters of standard-setters. As illustrated in Figure 1, NAZCA and LPAA represent an umbrella for a diversity of non-state, and sub-state actors to commit climate action according to specified criteria by the orchestrators, such that actions needed to be grounded in science, have a demonstrable impact, and bring about transformative change toward carbon neutrality. LPAA and NAZCA are thereby instruments to increase intermediary availability: since the 2014 Lima summit, thousands of new initiatives have been registered in NAZCA.

Targets: At the end of the orchestration chain are states, private bodies, civil society actors, and individuals who are addressed by orchestrators through intermediaries (see Table 2 and Figure 1). Orchestration can either serve to create common rules for the conducts of states or serve as substitute or complement for state action by promoting regulation of private conduct of non-state actors, or by providing public good and services (Abbott et al 2016, p. 6). Orchestration through LPAA and NAZCA captures very much the second function as a complement to state action. Many of the initiatives in LPAA revolve around service provision, for example accelerating climate finance and providing clean energy (International Solar alliance, Africa Renewable Energy Initiative, Global Geothermal Alliance) or energy efficiency (Global Energy Efficiency Accelerator). LPAA and NAZCA, then, seek to direct the efforts of a plethora of actors on the ground.

\section{Typology of Orchestration}


Table 2 below typologizes the two mechanisms orchestrated by the UNFCCC Secretariat. These mechanisms are tools to support, steer, and mobilize intermediaries toward de-carbonization (Abbott and Bernstein 2015). While this article focuses on non-state actors, the various registries and platforms surveyed below encompass governments, intergovernmental networks and public-private partnerships. The intermediaries are the various private and public actors, or constellations of actors from business, local authorities and civil society. These actors sign-up voluntarily and are enlisted through a number of orchestration mechanisms as illustrated in Table 2.

[Insert Table 2: "Orchestration in the UNFCCC" about here]

\section{The Orchestration of Non-State Climate Governance: Democratic Legitimacy}

We now assess what LPAA and NAZCA mean for the democratization of orchestrated climate governance. Before undertaking this analysis, we recognize a methodological challenge in our assessment. Since the non-state initiatives are found in a number of registries, we cannot assess the potential of all individual initiatives or pledges. Instead we often rely on meta-analyses assessing the aggregate effects of these initiatives (Chan et al. 2016; Hsu et al. 2015). We argue that these metaassessments combined with our own empirical analysis of NAZCA and LPAA are sufficient to evaluate the democratic legitimacy of these orchestration efforts.

\section{Participation (and representation) of non-state actors}

Which non-state actors participate and who is represented in LPAA and NAZCA? To measure participation, we use the range of different types of non-state actors or, framed in UNFCCC terminology, nine constituencies that can participate. These groups are: environmental NGOs, business, indigenous people, women, trade unions, local governments, science and technology communities, farmers, and youth. We supplement this by looking at the split between global North and global South participation.

To begin, LPAA is a high-level initiative orchestrated by the quartet mentioned previously. The 77 climate commitments from various actors under the LPAA umbrella have been showcased through events at COPs aimed at mobilizing 
non-state climate action. For accredited non-state observers at COPs, which amounted to more than 8200 participants at Paris, the LPAA action days and thematic events were open for participation to non-state actors from all nine constituencies. Moreover, representatives of constituencies such as environmental NGOs, indigenous people, and the science community were invited to speak at sessions.

The UN climate summit in Morocco at COP22 focused on continuation of the LPAA through its successor - Global Climate Action. In their submissions to the GCA Roadmap, many observers and parties have moved beyond the efforts in Paris to call for more balanced participation to represent the diversity of non-state actors, such as indigenous people, women, but also underrepresented actors such as business in developing countries (WRI 2016; UNFCCC 2016b).

In these ways, LPAA seeks to galvanize non-state actor networks, IOs, and states in their commitments to both NAZCA and NDCs. This practice of ratcheting up commitments through LPAA has occurred throughout 2015 at the June 'Business Summit' in Paris, the July 'Climate and Territories World Summit' in Lyon, the September 'World Water Week' in Stockholm, and the October 'Cool Earth Summit' in Japan. The LPAA covers non-state actor initiatives in 12 thematic areas as diverse as forestry management, agriculture, transport, the building sector, private finance, short-lived climate pollutants, cities, and renewable energy. General concepts such as 'resilience' and 'innovation' are strung throughout different areas of concrete action.

Based on these efforts, we argue that LPAA is significantly inclusive and equitable as it reflects a multi-stakeholder logic. This speaks in favor of the participatory quality of high-level orchestration efforts as the orchestrator (in this case, the UNFCCC) has been able to build and sustain the LPAA which gives a range of non-state actors access to set the agenda for future UNFCCC and state efforts.

The NAZCA portal, a bottom-up orchestration effort, contains more than 12500 individual commitments and numerous cooperative initiatives under various LPAA themes that are jointly undertaken by subnational actors and firms. Generally speaking, we identify three problems that emerge in terms of equal participation for NAZCA. First, as an open initiative, the geographical participation of non-state actors is unevenly distributed. We coded all 12522 NAZCA contributions based on the home country in which the contribution is registered. From this, we estimate that $87.1 \%$ of the contributions come from the Global North $(n=10907)$ while only $12.9 \%$ come 
from the Global South $(n=1615) .{ }^{6}$ This is complicated by the fact that many of the contributions come from actors that have networks spanning the North-South divide, but it still indicates that the lead is being taken in the North and not led by actors in the South. This figure is roughly confirmed by the Galvanizing the Groundswell of Climate Actions (2015) report which finds that $84 \%$ of the contributions to NAZCA come from OECD countries.

Second, the non-state actors who document commitments are self-selected. Because it is an 'opt-in' scheme, actors have to fit within one of the existing NAZCA categories. While these groupings are important, they are far from comprehensive with issues such as marine transport missing (although the global freight initiative may have some scope for marine transport mitigation $\left.{ }^{7}\right)$. This is important because the burden to ensure inclusive orchestration efforts falls on the UNFCCC in their role as orchestrator. The Secretariat should be employing orchestration in ways that set open agendas and mobilize wide-ranging support, rather than limiting the agenda and scope.

Third, there is no mechanism to ensure that the included commitments actually respond to the preferences and interests of affected parties. For instance, the Kellogg Company documents a wide array of affected parties who are considered in their NAZCA commitment (Kellogg Business 2015). In contrast, many of the private financing initiatives - such as the green bonds - provides little to no information about how these bonds will impact (or respond to) the needs of those affected by investment in different sectors (Climate Bonds 2015). This problem has recently become more acute as it becomes clear that actors who have committed to divestment and sustainability practices listed with NAZCA - such as Credit Suisse - provide multi-billion dollar loans to companies engaged in Palm Oil extraction and thus deforestation. ${ }^{8}$ Given that these companies gain legitimacy from participation in the NAZCA portal and yet act in ways that undermine the Paris Agreement, the UNFCCC should be held responsible for the effects of their orchestration efforts as they impact local and indigenous people on the ground.

On balance, then, we suggest that LPAA and NAZCA can offer inclusive and

\footnotetext{
${ }^{6}$ Coding on file with authors.

${ }^{7}$ See http://www.globalgreenfreight.org/ (accessed 20 April 2017).

${ }^{8}$ See http://www.nytimes.com/2016/12/03/business/energy-environment/how-big-banks-are-puttingrain-forests-in-peril.html?_r=0\%20and\%20https://www.cdp.net/en/responses/5834 (accessed 20 April 2017).
} 
participatory processes. Accordingly, LPAA is equitable in terms of including a range of non-state actor positions and even includes selection criteria to ensure accepted proposals are science-based, ambitious, inclusive, and possible to monitor. ${ }^{9}$ However since both orchestration efforts contain pre-determined categories, only intermediaries that can comply with these categorization efforts can be included. This has the effect of limiting the agenda setting power of intermediaries and affected parties as the rules are set by the orchestrator.

\section{Deliberation}

How can deliberation be secured under orchestration so affected individuals can receive and contest justifications for decision-making by both the UNFCCC as orchestrator and the policies of intermediaries? On both points, it is clear that NAZCA and LPAA come up short, though again with LPAA faring better.

Starting with LPAA, this process fares reasonably well in terms of deliberative justification for two reasons: its multi-stakeholder design and clearer criteria of inclusion, and we discuss both in turn. First, this mode of high-level orchestration to mobilize civil society is an established practice in UN diplomacy since the first UN Conference on Environment and Development in 1992 (Abbott and Bernstein 2015). The LPAA thematic events at Paris COP21 offered venues for deliberation between governments and societal stakeholders. In the submissions for the Roadmap for Global Climate Action in advance of COP22, both parties and observers stressed the need to enhance dialogue between business, civil society, and subnational actors at and between COPs. These events have offered more direct justifications to some elements of civil society though, as with NAZCA, these justifications are not systematically offered to affected parties. This is because justifications in these fora are limited to accredited observer organizations at the COP or those who are able to view the webcasts.

Second, the UNFCCC has publicized and justified the criteria for LPAA inclusion and tailored these criteria according to the type of participation (such as contributions by states, cities, business, and civil society). These criteria comprise justificatory demands such as monitoring and reporting on a regular basis,

${ }_{9}^{9}$ http://newsroom.unfccc.int/lpaa/join-lpaa/\#Criteria (accessed 20 April 2017). 
demonstrating capacity to deliver on commitments, showcasing contributions in public ways, and "observ[ing] inclusiveness (e.g. balance regional representation)."10 Alternately, NAZCA discussed in the next section, only made its criteria for inclusion available in the GCA launched at Marrakesh (UNFCCC 2016a). As such, we find several positive efforts at justification by the UNFCCC and LPAA intermediaries.

The same cannot be said of NAZCA as the quality and level of justifications in the commitments by intermediaries under this bottom up orchestration effort vary widely: Some non-state actors provide fairly comprehensive timelines to reach their commitments (for instance Kellogg and the city initiatives through the Covenant of Mayors), while others provide only minimal justifications for their actions. And there is little oversight by the UNFCCC to ensure that these justifications are diffused widely. As noted on the NAZCA portal, all commitments are documented, but only 'a small sample of the data' is released publicly (NAZCA 2015). In another example of this lack of justification, in order to view the NAZCA commitments for many companies, individuals have to register with the CDP and obtain approval from the organization to view commitments in detail (NAZCA CDP 2015). While the CDP does monitor these contributions, collect data, and publicize results, they do not aggregate the NAZCA data, nor are there sanctions for contributors who fail to report adequately. While there is a percentage ranking indicating how complete an annual report from a contributor is, the CDP explicitly says that a missing score does not indicate a lack of environmental impact, but may be a reporting error. This means that in-depth justifications about commitment levels, strategies, and outputs are substantially obscured from affected parties.

There are also few ways for the UNFCCC to monitor the implementation of NAZCA commitments. The decision by the UNFCCC to establish a bottom-up portal that they do not (or even cannot) monitor closely has not been directly justified by the UNFCCC. This is important because establishing NAZCA entails the use of public authority and it makes it difficult for affected individuals to understand how these actions could be seen as a credible commitment for tackling climate change. Because the COP decision to the Paris Agreement refers to both LPAA and NAZCA efforts as critical for ensuring that state commitments are ratcheted up over time, this gap must be taken seriously. By engaging a process of orchestration that stretches chains from

\footnotetext{
${ }^{10}$ See the criteria at http://newsroom.unfccc.int/lpaa/join-lpaa/ (accessed 20 April 2017).
} 
the Secretariat on to the intermediary and then to watchdogs, it becomes clear that both the Secretariat and intermediaries are able to circumvent their duty to justify their activities. As states seek to reach the goals of the Paris Agreement and the UNFCCC employs orchestration in this pursuit, justifying both the criteria for NAZCA inclusion and the activities of intermediaries would increase democratic legitimacy and make it clearer where implementation gaps exist.

Ultimately, then, the level of deliberative quality offered by the UNFCCC both for and within NAZCA and the LPAA varies substantially. Justifications range considerably in depth and quality, but affected actors are excluded from both intermediary goals and the monitoring of orchestrated targets by the UNFCCC under NAZCA. Due to the clearer criteria under LPAA individual actors can more clearly understand the justifications for inclusion and action of intermediaries. As orchestration becomes an increasingly important governance practice directed by the UNFCCC to include and manage non-state actors, these shortcomings of deliberative legitimacy should be taken seriously.

\section{Accountability and Transparency}

As transparency and accountability are inextricably linked, we treat them in a single sub-section (however we disaggregate the two values in our matrix below). An important precondition for holding actors accountable is the availability and access to information through public disclosure (Bäckstrand 2008, Peixoto 2013). Without transparency, monitoring and tracking of progress, the aggregate impact of non-state commitments will be hampered which will, in turn, weaken accountability of both the UNFCCC and intermediaries. Resultantly, strengthening transparency and accountability of the broader range of non-state climate action has become a leitmotif of both the High-Level Champions in the roadmap climate action as well as in most submissions both from Parties and observers.

In terms of democratic legitimacy, it is important that accountability and transparency of LPAA and NAZCA are offered to affected individuals. Transparency and accountability are, in the words of the WRI (2016, p. 3), therefore critical to 'establish credibility and legitimacy of the Action Agenda, and to build trust among the stakeholder involved'. Accountability can be achieved through non-state mechanisms that monitor, compare, and review the ambitions of NDCs in ways 
sensitive to affected individuals, by considering their views and providing them with information. The important role of civil society and research organizations outside the UNFCCC to assess whether non-state commitments fulfill their own targets are emphasized by several parties. ${ }^{11}$ These mechanisms can work to both positively sanction good effort from frontrunners and negatively sanction laggards through naming and shaming.

Accountability should then be seen as an important means by which the performance, progress, and implementation of non-state initiatives can be measured and linked to affected stakeholders. Accountability mechanisms in orchestration operate at two tiers. First, accountability is made possible if there are mechanisms to track whether the aggregate effect of climate actions in a registry help achieve climate goals. Here, the role of an orchestrator should be to set up appropriate mechanisms to ensure clarity, credibility, comparability, and transformative potential of climate commitments to affected parties. To that end the High-Level Champions have called for tracking of non-climate initiatives to examine if their targets are consistent with the long-term goals of the Paris Agreement and demonstrate their transformational potential (UNFCCC 2016a). The second tier of accountability relates to the varying accountability mechanisms for the climate actions in the registries of LPAA and NAZCA, and whether affected individuals can view and sanction these efforts. We discuss both tiers of accountability, i.e. how accountability can be enhanced through NAZCA and the LPAA employed by orchestrators, and the accountability of intermediary efforts.

A common theme in many of the recent reports on non-state climate commitments is the chronic lack of - and need for - stronger transparency and accountability (Chan et al. 2015, Hsu et al. 2015). A structural problem related to the various registries is that submission and reporting on initiatives occur on a voluntary basis and by means of self-description by various corporate, sub-state, and civil society actors. Yet the accountability of both LPAA and NAZCA are significantly lacking as the orchestrator is still in the process of setting up benchmarking, review procedures, or monitoring mechanisms so that stakeholders and governments can track process, compare performance, and identify best practices among the different

\footnotetext{
${ }^{11}$ This is reflected in the submissions by many parties and observers as well as in the synthesis report of the High-Level Champions (2016c), http://unfccc.int/documentation/items/9636.php (accessed 20 April 2017).
} 
initiatives (UNFCCC 2016c). With the emergence of the GCA, this lack of accountability and transparency has been officially recognized as the High-Level champions note: 'We need to help non-Party stakeholders achieve the recognition they seek. At the same time, we owe it to the integrity of the UNFCCC process to make sure that these initiatives and coalitions achieve the targets they set for themselves; that these targets are truly consistent with the long-term goals of the Paris Agreement; and that the participants in initiatives and coalitions are actually doing what it takes to achieve the commitments they made. ${ }^{12}$

To be sure, during the early stages of NAZCA and the LPAA, the CDP and the Carbon $n$ Climate Registry undertook data tracking of these initiatives. By December of 2015, this had expanded to include: The Climate Group, Investors on Climate Change, the UN Global Compact, Covenant of Mayors, and Climate Bonds Initiative (UNFCCC 2015a). By the commencement of COP21 in Paris, there were over 10500 commitments from a host of cities, regions, companies, investors, and NGOs. In the COP21 decision annexed to the Paris Agreement, LPAA and NAZCA are mentioned as important mechanisms for non-party stakeholders to scale-up their climate actions to 2020 (UNFCCC 2015c, para 177-121). However, as discussed previously, the UNFCCC is only now taking steps to ensure that NAZCA commitments and LPAA goals are being justified to individuals, that data is easily accessible, or that affected individuals can contest the goals of intermediaries or the UNFCCC's orchestration efforts.

In this vein, many initiatives under LPAA and NAZCA lack quantifiable longterm goals and targets, screening, and monitoring mechanisms. A precondition for holding actors accountable for their climate actions is clear, quantifiable, and measurable targets. However, only a third of the 77 cooperative initiatives under the LPAA have mitigation targets (Galvanizing the Groundswell of Climate Action 2015, p. 10).

Weak accountability is problematic given that non-state initiatives in NAZCA and the LPAA are framed as complementary or even compensatory mechanisms for lack of governmental action and multilateral action on climate change. However, there are many sobering accounts of the prospect of non-state action to reduce the ${ }^{12}$ See http://newsroom.unfccc.int/climate-action/global-climate-action-agenda (accessed 20 April
2017). 
emission gap and contribute to low carbon society. Several studies point to the problems of 'additionality' and 'double accounting' of national pledges and international initiatives. This refers to overlap between governments' national climate plans and their registered pledges and participation in NAZCA and LPAA (Chan et al. 2015, Hsu et al. 2015).

However, since initiatives encompass a diversity of actors, networks, and coalitions - elected mayors, investors, civil society, companies and regional governments - accountability mechanisms may be in place for individual initiatives. Electoral and non-electoral accountability may operate in initiatives, for example mayors are held accountable by citizens, corporations by their stakeholders, and civil society organizations by their members. It seems plausible, though, that public scrutiny of the UNFCCC decision to engage in orchestration, as well as the activities of intermediaries, will also help curtail some of the governance gaps noted in current studies. Public accountability and transparency will increase the number of actors who can monitor intermediary efforts and report on non-compliance. It will likewise pressure the UNFCCC to monitor intermediaries more carefully as they construct criteria for inclusion and repeatedly claim that these efforts are essential in reaching the lofty goals of the Paris Agreement.

But ultimately there are many shortcomings in how orchestrated contributions are being measured in practice and a lack of ability for affected individuals to a) hold the UNFCCC accountable for failing to ensure that initiatives do not overlap, or b) hold intermediaries to account for failing to realize their commitments or take consideration for how their actions do or do not impact affected actors on the ground. For these reasons we label both LPAA and NAZCA as having nascent or even absent accountability and transparency mechanisms in place. However, the adoption of the Marrakech Partnership for Global Climate Action indicates that questions of transparency, tracking, and accountability of climate action will increasingly be addressed (UNFCCC 2016b).

\section{Summarizing Democratic Potential and Pitfalls}

Table 3 summarizes how democratic values stack up in existing orchestration attempts by the UNFCCC. First, we see a difference between high-level orchestration mechanisms (LPAA) through multi-stakeholder diplomacy and 'bottom-up 
orchestration' (NAZCA) through registries and platforms for non-state actions. The high-level orchestration undertaken by state parties and Secretariats jointly - where pledging takes place in conjunction with COPs- engage and mobilize a broader range of stakeholders from business, civil society, and municipalities in different geographical regions. In terms of balanced participation of different groups of nonstate actors, then, LPAA scores better than NAZCA. But it is worth re-iterating that this situation is changing as the High-Level Champions call for more balanced and diverse participation in both LPAA and NAZCA in the GCA Roadmap (UNFCCC 2016b). But at this stage the high-level orchestration provides a venue for deliberation of voluntary pledges by cities, corporations and coalition or networks of actors as these are publically justified and debated. This 'pledging diplomacy' and showcasing runs the risk of being 'green washing'. And we are wary that high-level summits may contain a trade-off: it is easier to obtain a good spread of civil society actors by drawing upon accredited bodies within the UNFCCC, but this runs the risk of disregarding affected actors on the ground who are not accredited at official events. Still orchestration through summits entails an open, inclusive and deliberative process, in which actors can be held accountable for their (in)actions.

In contrast, the bottom-up character of NAZCA in which non-state actors submit their pledges is less balanced in terms of participation - and heavily skewed toward state and sub-state actors and governmental partnerships in the global North. . Since the UNFCCC Secretariat only provides limited guiding principles, templates, or screening of what constitutes a 'climate action' or 'cooperative initiative' for NAZCA, it includes all kind of actions related to climate change, and encompasses any type of actor. Transparency and accountability in these types of orchestration mechanisms are also nascent of non-existent as there is insufficient screening, lack of criteria for what qualifies as a climate target and quantitative targets with respect to greenhouse gas reductions, and weak monitoring mechanism for assessing targets by affected stakeholders.

[Insert Table 3: "Democratic values in orchestration" about here]

\section{Conclusion}

This article has had two main objectives. Theoretically we have shed light on the 
neglected normative dimension of orchestration, in this case, its democratic legitimacy. Although delegation (in terms of principal-agent models) can rely predominantly on chains of accountability that give some affected individuals control of IO decisions, orchestration does not fit this mold. Indeed the entire concept has arisen from the recognition that IOs, states, and other public bodies are exerting their authority through soft modes of governance (steering other actors, mobilizing new efforts, even helping to craft $3^{\text {rd }}$ party rules). We have fleshed out the democratic problem related to orchestration, showed its importance at the interface of UN climate diplomacy and non-state action, and taken stock of how different democratic values participation, deliberation, accountability, and transparency - fare in recent orchestration attempts.

Our empirical findings suggest that the fulfillment of democratic values varies between individual or joint orchestration attempts undertaken by Secretariats of the UNFCCC and the UN Secretary-General and COP presidencies, coinciding with the division we denote between high-level orchestration and bottom-up orchestration. High-level efforts, exemplified by the LPAA, promote more balanced participation and deliberative processes compared to bottom-up orchestration found in various overlapping registries, platforms, and databases for non-state climate commitments such as NAZCA. However, for the two orchestration attempts by the UN surveyed, transparency and accountability mechanisms are nascent at best or non-existent at worse. There is very limited possibility for affected individuals to track the environmental additionality, performance, and effectiveness of these non-state initiatives thus obscuring decisions and decision-making from individuals.

Second this argument has limitations, which, simultaneously, provide future directions for research. We have taken a first cut at evaluating the democratic legitimacy of orchestration. Further work is required to determine the trade-offs between these values and to assess how feasible these values are given the limited resources of the UNFCCC Secretariat and the difficulties of securing compliance. Empirically we have only undertaken analysis within the field of climate governance. It remains an open question whether orchestration in different issue-areas is democratically legitimate (and to what extent).

Finally, future scholars should attempt to isolate how different democratic values contribute to enhancing governance functions as we move into the post-Paris climate regime where orchestration is expected as a key strategy, clearly manifest in 
the orchestrated Marrakech Partnership for Global Climate Action adopted at COP22. Orchestration has emerged as an increasingly important practice when top-down targets and timetables have been replaced by voluntary pledge and review. Assessing early examples - such as the LPAA and NAZCA - helps expose the democratic promises and pitfalls facing the UNFCCC, states, and non-state actors as the GCA become a key instrument for involving non-state actors in the post-Paris period. Previous discussions of orchestration (and, relatedly, regime complexity and fragmentation) in climate governance have only tackled normative questions in an embryonic fashion. This paper suggests reasons why, and a strategy how, to alter current scholarship and take normative questions seriously.

\section{References}

Abbott, K. and Bernstein, S., 2015. The High-Level Political Forum on sustainable development: Orchestration by default or design. Global Policy, 6 (3), 222-233.

Abbott, K., Genschel, P. Snidal, D. and Zangl, B., eds., 2015a. International organizations as orchestrators. Cambridge, UK: Cambridge University Press.

Abbott, K, Genschel P., Snidal. D. and Zangl, B., 2015b. Two logics of indirect governance: delegation and orchestration. British Journal of Political Science, DOI: http://dx.doi.org/10.1017/S0007123414000593.

Bäckstrand, K., 2008. Accountability of networked climate governance: the rise of transnational climate partnerships. Global Environmental Politics, 8 (3), 74-104.

Bulkeley, H. et al., 2014. Transnational climate change governance. Cambridge: Cambridge University Press.

Chan, S., Brandi, C. and Bauer, S., 2016. Aligning transnational climate action with international climate governance: The road from Paris. Review of European Community and International Environmental Law, 25(2), 238-247.

Chan, S. et al., 2015. Reinvigorating international climate policy: A comprehensive framework for effective non-state action. Global Policy, 6 (4), 466-473.

Climate Bonds, 2015. Available at: http://www.climatebonds.net/cbi/pub/data/bonds [accessed December 5, 2015].

Clémencon, R., 2016. Two sides of the Paris climate agreement: dismal 
failure or historic breakthrough. Journal of Environment and Development, 25 (1), 3-24.

Dingwerth, K., 2007. The new transnationalism. transnational governance and legitimacy. London: Palgrave MacMillan.

Dingwerth, K., 2014. Global democracy and the democratic minimum: why a procedural account alone is insufficient. European Journal of International Relations, 20 (4), 1124-1147.

Falkner, R., 2016. The Paris Agreement and the new logic of international climate Politics. International Affairs, 95 (2), 1-28.

Galvanizing the Groundswell of Climate Actions, 2015. Lima-Paris Action Agenda independent assessment report. Available at: http://www.climategroundswell.org/blog-test/lpaa/report [accessed December 7, 2015].

Grant, R., and Keohane, R. O., 2005. Accountability and abuses of power in world politics. American Political Science Review, 99 (0031), 29-44.

Habermas, J., 1996. Between facts and norms. Cambridge MA: MIT Press.

Hale, T. and Roger, C., 2014. Orchestration and transnational governance. Review of International Organization, 9 (1), 59-82.

Hale, T., 2016. "All Hands on Deck": The Paris Agreement and non-state climate action. Global Environmental Politics, 16 (3), 12-21.

Hsu, A., Moffat, A.S., Weinfurter, A.J. and Schwartz, J.D., 2015. Towards a new climate diplomacy. Nature Climate Change, 5 (6),501-503.

Hoffmann, M., 2011. Climate governance at the cross-roads. Experimenting with a global response after Kyoto. Oxford: Oxford University Press.

Johnson, T., 2013. Institutional design and bureaucrats' impact on political control. Journal of Politics. 75 (01), 183-197.

Keohane, R.O., Macedo, S. and Moravcsik, M., 2009. Democracyenhancing multilateralism. International organization. 63 (1), 1-31.

Kellogg Business (2015). Available at: https://business.un.org/en/commitments/4008\#overview [accessed November $15,2015]$.

Kuyper, J., 2015. Gridlock in global climate change negotiations: two democratic arguments against minilateralism. In: $\mathrm{C}$. McKinnon and A. Maltais, eds. The ethics of climate governance. Where?:Rowman and Littlefield Press, 67-88. 
Macdonald, T., 2008. Global stakeholder democracy. Power and representation beyond liberal states. Oxford: Oxford University Press.

Moravcsik, A., 2004. Is there a 'democratic deficit' in world politics? A framework for analysis. Government and opposition, 39 (2), 336-363.

NAZCA., 2015. Available at: http://climateaction.unfccc.int/about[accessed 15 November, 2015].

NAZCA CDP., 2015. Available at: http://nazca.cdp.net/ [accessed 2 December 2015].

Peixoto, T., 2013. The uncertain relationship between open data and accountability: A response to Yu and Robinson. UCLA Law Review, 60, 200-48.

Stevenson, H. and. Dryzek, J. S., 2014. Democratizing global climate governance. Cambridge: Cambridge University Press.

UNFCCC,2015a, 'About NAZCA'. Available at: http://climateaction.unfccc.int/about [accessed 20 November 2015].

UNFCCC, 2015b. Paris agreement. FCCCC/CP/2015/L.9/Rev.1.

UNFCCC, 2015c. Draft decision -/CP.21. FCCCC/CP/2015/L.9/Rev.1.

UNFCCC, 2016a. Marrakech Partnership for Global Climate Action. Available at: https://unfccc.int/files/paris_agreement/application/pdf/marrakech_partnership _for_global_climate_action.pdf [accessed December 9, 2016].

UNFCCC, 2016b. Roadmap for global climate action. Available at: http://newsroom.unfccc.int/media/658505/high-level-champions-climateaction-roadmap.pdf [accessed December 9, 2016].

UNFCCC, 2016c. Submissions on the roadmap for global climate action. Synthesis written by the COP21 and COP22 team. Available at: http://newsroom.unfccc.int/media/764014/synthesis-report_submissions-onthe-roadmap-for-global-climate-action.pdf [accessed December 9, 2016].

WRI, 2016. Submission from World Resources Institute on the Roadmap for global climate action. August 1, 2016. Available at: http://unfccc.int/files/parties_observers/submissions_from_observers/applicati on/pdf/649.pdf [accessed, October 17, 2016]. 
Tables with caption(s) (on individual pages)

Table 1. Standards for Assessing Democratic Values

\begin{tabular}{|c|c|c|c|c|}
\hline $\begin{array}{l}\text { Presence } \\
\text { Democratic } \\
\text { Value }\end{array}$ & Significant & Limited & Nascent & Absent \\
\hline Participation & $\begin{array}{l}\text { Agenda setting and } \\
\text { decision-making is } \\
\text { consistently equal } \\
\text { and inclusive }\end{array}$ & $\begin{array}{l}\text { Agenda setting } \\
\text { and decision- } \\
\text { making is } \\
\text { sometimes } \\
\text { unequal and } \\
\text { exclusive }\end{array}$ & $\begin{array}{l}\text { Agenda setting and } \\
\text { decision-making is } \\
\text { systematically } \\
\text { unequal and } \\
\text { exclusive }\end{array}$ & $\begin{array}{l}\text { Participation is } \\
\text { entirely absent }\end{array}$ \\
\hline Deliberation & $\begin{array}{l}\text { Justifications are } \\
\text { consistently } \\
\text { mutually acceptable } \\
\text { and provide equal } \\
\text { opportunity to } \\
\text { question decision- } \\
\text { making }\end{array}$ & $\begin{array}{l}\text { Justifications are } \\
\text { sometimes } \\
\text { offered and } \\
\text { individuals are } \\
\text { sometimes } \\
\text { excluded from } \\
\text { questioning } \\
\text { decision-making }\end{array}$ & $\begin{array}{l}\text { Justifications for } \\
\text { authority are weak } \\
\text { and individuals are } \\
\text { systemically } \\
\text { excluded from } \\
\text { questioning decision- } \\
\text { making }\end{array}$ & $\begin{array}{l}\text { No justifications are } \\
\text { offered and } \\
\text { individuals have no } \\
\text { ability to question } \\
\text { decision-making }\end{array}$ \\
\hline Accountability & $\begin{array}{l}\text { Standards are clear } \\
\text { and affected } \\
\text { individuals can } \\
\text { consistently } \\
\text { question and } \\
\text { sanction deviation }\end{array}$ & $\begin{array}{l}\text { Standards are } \\
\text { sometimes } \\
\text { unclear and } \\
\text { sanctioning is } \\
\text { only sometimes } \\
\text { available }\end{array}$ & $\begin{array}{l}\text { Standards are } \\
\text { systematically } \\
\text { unclear and } \\
\text { sanctioning is rarely } \\
\text { available }\end{array}$ & $\begin{array}{l}\text { Standards are } \\
\text { entirely absent and } \\
\text { sanctioning is not } \\
\text { available }\end{array}$ \\
\hline Transparency & $\begin{array}{l}\text { Clear and accurate } \\
\text { information is } \\
\text { consistently } \\
\text { publically available }\end{array}$ & $\begin{array}{l}\text { Information is } \\
\text { sometimes } \\
\text { unclear and } \\
\text { difficult to access }\end{array}$ & $\begin{array}{l}\text { Information is } \\
\text { routinely unclear and } \\
\text { difficult to access }\end{array}$ & $\begin{array}{l}\text { Information is } \\
\text { unavailable }\end{array}$ \\
\hline
\end{tabular}


Table 2. Orchestration in the UNFCCC

\begin{tabular}{|c|c|c|}
\hline & \multicolumn{2}{|c|}{ Meta-intermediaries } \\
\hline & $\begin{array}{l}\text { Lima-Paris Action } \\
\text { Agenda (LPAA) }\end{array}$ & $\begin{array}{l}\text { Non-state Actor Zone of Climate } \\
\text { Action (NAZCA) }\end{array}$ \\
\hline Orchestrator & $\begin{array}{l}\text { Quartet of COP } \\
\text { presidencies, UNSG } \\
\text { secretariat, UNFCCC } \\
\text { secretariat }\end{array}$ & UNFCCC Secretariat \\
\hline Intermediaries & $\begin{array}{l}\text { Business, } \\
\text { transgovernmental } \\
\text { networks, subnational } \\
\text { actors, civil society, } \\
\text { governments, public- } \\
\text { private partnerships }\end{array}$ & $\begin{array}{l}\text { Corporations, investors, cities and } \\
\text { subnational authorities, civil society }\end{array}$ \\
\hline Targets & $\begin{array}{l}\text { States } \\
\text { Private actors (business } \\
\text { and civil society) }\end{array}$ & $\begin{array}{l}\text { States } \\
\text { Private actors (business, civil } \\
\text { society) }\end{array}$ \\
\hline Function & $\begin{array}{l}\text { Implementation of pre- } \\
2020 \text { climate action }\end{array}$ & $\begin{array}{l}\text { Implementation of pre-2020 climate } \\
\text { action }\end{array}$ \\
\hline Type of action & $\begin{array}{l}\text { Cooperative initiatives by } \\
\text { coalition of actors }\end{array}$ & Commitments by individual actors \\
\hline Number of actions & 77 & 12,522 \\
\hline
\end{tabular}

Table 3. Democratic values in orchestration

\begin{tabular}{|l|l|l|}
\hline & LPAA & NAZCA \\
\hline Participation & $\begin{array}{l}\text { Significant } \\
\text { Multi-stakeholder }\end{array}$ & $\begin{array}{l}\text { Limited } \\
\text { Cities and companies } \\
\text { dominate }\end{array}$ \\
\hline Deliberation & $\begin{array}{l}\text { Significant } \\
\text { Public justification of } \\
\text { pledging }\end{array}$ & $\begin{array}{l}\text { Limited } \\
\text { Deliberation limited to } \\
\text { individual } \\
\text { Initiatives for example PPPs }\end{array}$ \\
\hline Accountability & $\begin{array}{l}\text { Nascent or Absent } \\
\text { Emerging metrics for } \\
\text { assessing contributions }\end{array}$ & $\begin{array}{l}\text { Nascent or Absent } \\
\text { Emerging metrics for } \\
\text { assessing contributions }\end{array}$ \\
\hline Transparency & $\begin{array}{l}\text { Significant } \\
\text { Public information of } \\
\text { targets }\end{array}$ & $\begin{array}{l}\text { Limited } \\
\text { Public information of targets }\end{array}$ \\
\hline
\end{tabular}


Figure 1: Orchestration

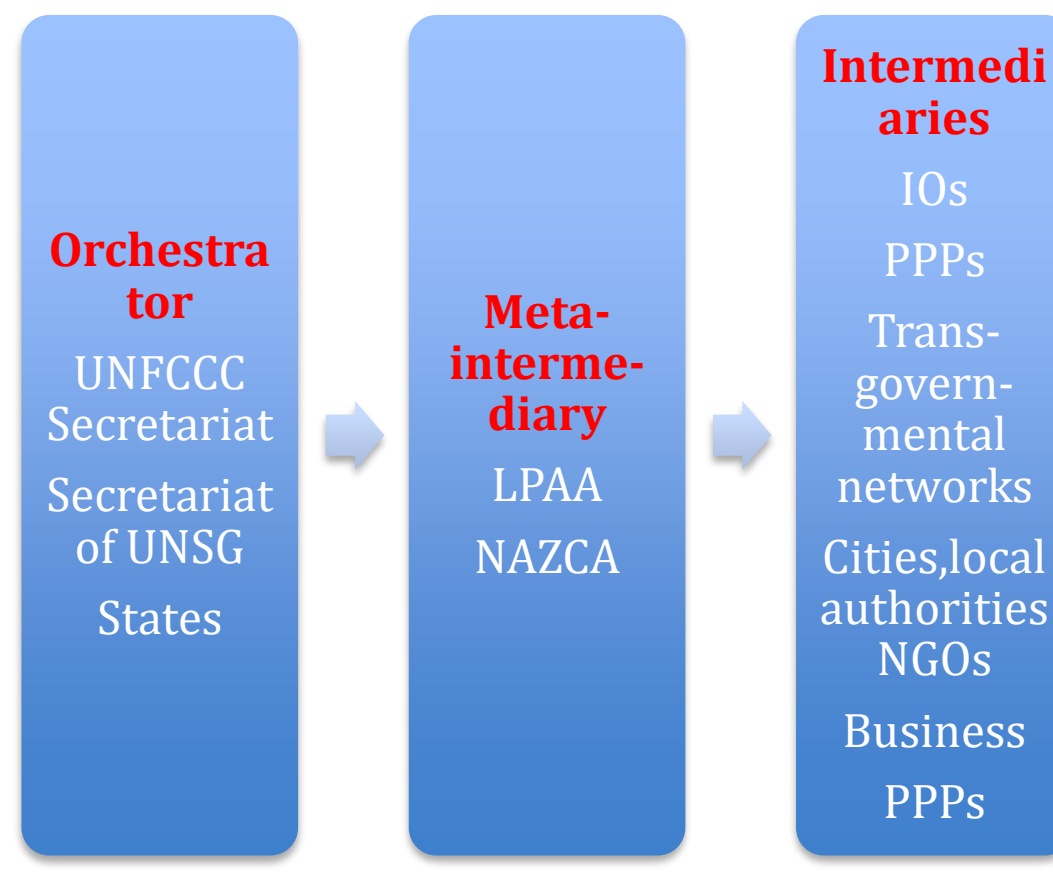

